\title{
Comparative study of the bioactive and chemical properties of three different Solanum spp. from Ghana
}

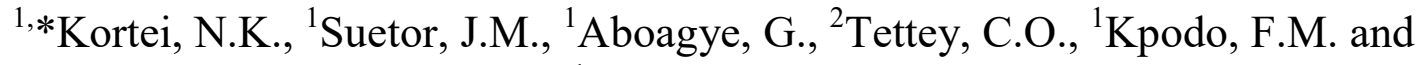 \\ ${ }^{1}$ Essuman, E.K. \\ ${ }^{I}$ Department of Nutrition and Dietetics, School of Allied Health Sciences, University of Health and Allied \\ Sciences, PMB 31, Ho, Ghana \\ ${ }^{2}$ Department of Biomedical Sciences, School of Basic and Biomedical Sciences, University of Health and \\ Allied Sciences, PMB 31, Ho, Ghana
}

\begin{abstract}
Article history:
Received: 1 January 2020

Received in revised form: 8 April 2020

Accepted: 14 April 2020

Available Online: 4 July 2020

Keywords:

Solanum spp.,

Solanum torvum,

Solanum erianthum,

Solanum macrocarpon,

Antioxidants,

Mineral elements
\end{abstract}

\section{DOI:}

https://doi.org/10.26656/fr.2017.4(5).010

\begin{abstract}
The family Solanaceae represent one of the most economically, nutritionally and medicinally important families of angiosperms. The genus Solanum is a hyper-diverse taxon of this family. There are about 2300 species of Solanum in the world that are mainly distributed in the tropical and sub-tropical areas, with a small number in the temperate areas. Solanum torvum has been extensively explored for its chemical constituents. To determine and compare the phytoconstituents of the fruits/berries of three different species of Solanum (torvum, erianthum, and macrocarpon) at different maturity stages. Fruits of Solanum (torvum, erianthum, and macrocarpon) were harvested at different maturity stages from local farms and around households in the Volta region and kept in sterile sample bags. Phytochemical and mineral analysis of the fruits was carried out according to the method of the Association of Official Analytical Chemists (AOAC), to determine the mineral composition of the fruits. Total phenolic content was determined by the Folin Ciocalteau method, Flavonoids content was determined by the Aluminum Chloride method. Antioxidant activity was determined by three assays; DPPH, FRAP, and ABTS. The elemental mineral analysis was done using the flame photometer according to methods by AOAC. The present study revealed that the levels of antioxidants, total phenolics, and flavonoids contents were significantly affected by both the physiological maturity stage and extraction solvents. Total phenolic content ranged between $16.97 \pm 0.03$ - 40.62 $\pm 0.00 \mu \mathrm{L}$ GAE $/ 10 \mu \mathrm{L}$. Flavonoids contents ranged from $52.33 \pm 0.36-434.00 \pm 0.31$ $\mu \mathrm{L} \mathrm{CE} / 10 \mu \mathrm{L}$. Antioxidants activity values ranged between $37.79 \pm 036-878.34 \pm 4.36$, $16.66 \pm 7.40-47.49 \pm 15.27$ and $0.075 \pm 0.00-0.257 \pm 0.00$ for DPPH, ABTS and FRAP assays respectively. Elemental mineral values recorded ranged between $4.87 \pm 0.03$ $11.55 \pm 0.05 \mathrm{mg} / \mathrm{kg}$ for $\mathrm{Fe}, 23.23 \pm 0.04-32.46 \pm 0.04 \mathrm{mg} / \mathrm{kg}$ for $\mathrm{Mg}$ and $34.317 \pm 0.03-$ $15.3309 \pm 0.001 \mathrm{mg} / \mathrm{kg}$ for $\mathrm{Na}$. This study revealed that the levels of antioxidants, total phenolics and flavonoids are significantly affected by both the physiological maturity stage and extraction solvents. It was clear that all methanolic extract showed significant variations with high values in antioxidants which included the DPPH scavenging activity, the $\mathrm{ABTS}^{\cdot+}$ scavenging activity, the Ferric reduction power assay, the total phenolics, and the flavonoid content.
\end{abstract}

\section{Introduction}

Solanaceae is a plant family comprising of about 2300 species and nearly one-half belong to the genus Solanum (Oppong et al., 2015). The genus Solanum is comprised of about 1500 species and well represented all over the world. Its genomics in the genus Solanum is evolving at a moderate pace compared to other plant species (Oppong et al., 2015). It is rich in alkaloids which are distributed in all parts of the plant. The active components such as solinidine and other steroids extracted from the roots and leaves of some species are potent and effective pharmaceuticals. The majority of the Solanum species are widely used in folk medicine (Sundari et al., 2013). Some example of species which belong to the genus Solanum are ficifolium, ferrugineum, 
torvum, erianthum, indicum L, trilobatum, xanthocarpum.

S. torvum is a common plant native to many tropical countries in Africa and the West Indies. It is also found in some parts of Asia. In Ghana and many other countries, the fruits are used for food. The leaves are used in many traditional medical practices in Africa (Nguelefack et al., 2008). The plant grows as a short (about 2-4 m tall), erect shrub with lots of branches. $S$. torvum grows into a large thorny impenetrable thicket (Mohan and Bhandare, 2012). The fruits are employed in traditional medicine to cure cough, bronchial asthma, liver, and spleen enlargement. The fruits of $S$. torvum are clusters of tiny green spheres (about $1 \mathrm{~cm}$ in diameter) that become yellow when fully ripen. They are thinfleshed and contain numerous flat, round, brown seeds (Akoto et al., 2015). In Ghana, S. torvum (locally referred to as 'Kwahu nsusua', 'Abeduro', 'Yaa Asantewaa', 'Kantosey' etc) is used essentially for food. In the south of Ghana, especially, it is added to palm nut soup and some stews (Akoto et al., 2015). S. torvum has both a sedative and a diuretic therapeutic effect. The leaves are used as a hemostatic. Phytochemical studies indicated that fruits of this species have good concentrations of various alkaloids, flavonoids, saponins, tannins, and glycosides which are sufficient to have pharmacological effects.

Solanum erianthum has been intentionally cultivated for food and medicine (Babalola et al., 2016). Like many members of the Solanaceae family, it contains bio constituents which are both highly toxic to humans and medicinally useful. This particular species possesses steroidal saponins and steroidal alkaloids that are useful in the pharmaceutical industry as steroidal precursors to produce anti-inflammatory corticosteroids, contraceptive steroids and anabolic steroids (Rasheed and Qasim, 2013). Essential oils in the fruits and leaves of $S$. erianthum have been studied for their traditional uses in medicine, especially for skin disease and stomach related ailment. The berries are cooked and eaten in Southeast Asia and made into curry in Southern India.

Solanum macrocarpon otherwise known as the African eggplant ("Gboma") belongs to the Solanaceae family (Haliński et al., 2019). It is a tropical biennial plant that is closely related to the eggplant; it grows to a height of 1-1.5 $\mathrm{m}$ and has an alternate leaf pattern with the blade width of $4-15 \mathrm{~cm}$ and a height of $10-30 \mathrm{~cm}$. The shapes of the leaves are oval and lobed with a wavy margin. The fruits are round, the top and the bottom are flattened out and have grooved portions with a length of $5-7 \mathrm{~cm}$ and a width of $7-8 \mathrm{~cm}$. The stalk of the fruit is $1-4 \mathrm{~cm}$ long and is either curved or erect. At a young stage, the color of the fruit is green, ivory, or purple and white color with dark stripes. When ripe, the fruit turns yellow or a yellow-brown. The fruit contains many seeds and it is partly covered by the calyx lobes. The seeds have a length of 3-4.5 $\mathrm{mm}$, a width of 2-3.5 $\mathrm{mm}$, and the shape is obovoid. S. macrocarpon has a large cultivar and varieties that grow in areas of high rainfall found (Haliński et al., 2019).

The Solanum species are popularly known and consumed all over the world for their health benefits and nutritive values. In Ghana majority of the species especially $S$. torvum is consumed based on the knowledge that they have hematinic properties and promote overall health and wellbeing as well as $S$. erianthum which is popularly consumed in Asia and parts of West Africa (Kuffuor et al., 2011). Though popularly known, little knowledge exists on the bioavailability of iron of these species. Locals have limited knowledge on the species that contain adequate and enough iron and even at different physiological maturity stages and hence tend to stick to one type especially with the fruits of $S$. macrocarpon which is underutilized due to lack of knowledge on its health benefits.

Several pieces of research conducted showed that turkey berries are a good source of iron. Extracts of the fruit possess high iron content and therefore justifying their use as hematinic (Akoto et al., 2015). Based on this knowledge, people are being advised to consume turkey berries without knowing which physiological maturity stage yields more nutrients and antioxidants, especially iron. Also due to lack of knowledge, only the leaves of $S$. marcrocarpon are consumed in certain parts of Ghana. This study aimed to determine and compare the mineral and phytochemical constituents of the fruits/berries of species of Solanum (torvum, erianthum, and marcrocarpon) at different physiological maturity stages.

\section{Materials and methods}

\subsection{Study design}

This study was a laboratory/bench work and employed a quantitative data collection method constituting various laboratory analyses of samples.

\subsection{Samples and chemicals}

\subsubsection{Samples}

Fruits/berries of Solanum (torvum, erianthum, and macrocarpon) (Figure 1) were sourced and harvested at different physiological maturity stages (early matured, matured and post matured) from farms and gardens in Ho and Tsito (Volta Region, Ghana) within the periods of September to December 2018. 


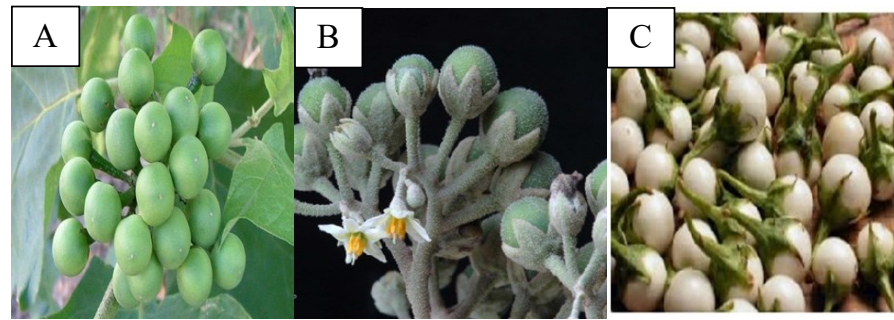

Figure 1. A- Solanum torvum, B - Solanum erianthum, C Solanum macrocarpon

\subsubsection{Chemicals}

The chemicals and reagents used for analyzing the mineral and phytochemical contents included gallic acid, catechin, sodium nitrate, sodium carbonate, Folin Ciocalteu phenol reagent, trichloro-acetic acid, sodium nitrite, aluminium chloride, methanol, HCL, 2, 2azinobis (3-ethylbenzothiazoline-6-sulphonic acid) diammonium salt (ABTS), 2, 4, 6-tripyridyl-S-triazine (TPTZ), $\mathrm{FeCl}_{3} .3 \mathrm{H}_{2} \mathrm{O}$, potassium persulphate, sodium acetate, Ascorbic acid and 2, 2-diphenyl-1picrylhydrazyl (DPPH).

\subsection{Sample preparation}

The samples were washed, sun-dried for a week and milled to a fine powder with a miller. The milled samples were then kept in a sterile sample bag for transport to study site and analysis. Samples were coded and labelled accordingly as follows:

$$
\begin{aligned}
& \mathrm{St}_{1}=\text { early/pre matured stage of } S . \text { torvum } \\
& \mathrm{St}_{2}=\text { matured stage of } S . \text { torvum } \\
& \mathrm{St}_{3}=\text { late/post matured stage of } S . \text { torvum } \\
& \mathrm{Se}_{1}=\text { early/pre matured stage of } S . \text { erianthum } \\
& \mathrm{Se}_{2}=\text { matured stage of } S \text {. erianthum } \\
& \mathrm{Se}_{3}=\text { late/post matured stage of } S . \text { erianthum } \\
& \mathrm{Sm}_{1}=\text { early/pre matured stage of } S . \text { macrocarpon } \\
& \mathrm{Sm}_{2}=\text { matured stage of } S . \text { macrocarpon } \\
& \mathrm{Sm}_{3}=\text { late/post matured stage of } S . \text { macrocarpon }
\end{aligned}
$$

\subsection{Elemental mineral analysis}

Standard solutions and aliquots of the diluted clear digest were used for flame photometry using the recommended standard methods of AOAC (2000) to determine the iron, magnesium and sodium content using atomic absorption spectrophotometry with protocols and standards established by the AOAC (2000).

\subsection{Sample extraction}

Ethanol $(70 \%)$ and methanol $(70 \%)$ were used for phenolic extraction. To $5 \mathrm{~g}$ of each dried powdered seed, $50 \mathrm{~mL}$ of ethanol $(70 \%)$ and methanol $(70 \%)$, was added in a $250 \mathrm{~mL}$ conical flask. The mixtures were shaken every 15 mins for $1 \mathrm{hr}$. The mixtures were then allowed to stand for $48 \mathrm{hrs}$ with occasional shaking, after which the mixtures were filtered using $125 \mathrm{~mm}$ filter paper to remove solid particles. The filtrates were then transferred into pre-weighed Petri dishes and then evaporated at $50^{\circ}$ $\mathrm{C}$ using a Heratherm oven to remove the ethanol and methanol. The extracts were then used to determine the total phenol content, total flavonoid, and antioxidant screening.

\subsection{Determination of total polyphenol content}

The total polyphenol content was calorimetrically estimated using Folin Ciocalteu reagent as described by Bhalodia et al., 2011) with modifications. About $50 \mathrm{~g}$ of each extract was dissolved in $1 \mathrm{~mL}$ of ethanol and vortexed. $5 \mathrm{~mL}$ of ethanol and $0.5 \mathrm{~mL}$ of Folin Ciocalteu's reagent were mixed and shaken. After 5 mins, $1.5 \mathrm{~mL}$ of $20 \%$ sodium carbonate was added and volume made up to $10 \mathrm{~mL}$ with ethanol. It was allowed to incubate for $2 \mathrm{hrs}$ at room temperature. The intense blue color was developed. After incubation, absorbance was measured at $750 \mathrm{~nm}$ using a UV spectrophotometer (Jenway Vis Spectrophotometer). The blank was performed using reagent blank with solvent. Gallic acid was used as a standard. The calibration curve was plotted using standard garlic acid. The total phenol content of the berries of Solanum spp. was quantified and expressed as Gallic Acid Equivalent (GAE) mg/g sample weight basis (DW) and the range of a calibration curve was from 0.067 to 1.562 .

\subsection{Total flavonoid content}

The total flavonoid content was determined by the aluminum chloride colorimetric assay with modifications. An aliquot of $5 \mathrm{~g}$ of the extracts was added to $10 \mathrm{~mL}$ test tubes containing $1 \mathrm{~mL}$ of ethanol. About $150 \mu \mathrm{L}$ of $5 \%$ sodium nitrite solution $(5 \%$ $\mathrm{NaNO}_{2}$ ) was added to each mixture and rested for 5 mins before the addition of $150 \mu \mathrm{L} 10 \%$ aluminum chloride $\left(10 \% \mathrm{AlCl}_{3}\right)$. The resulting mixture was then allowed to stay for another 5 mins before adding $1 \mathrm{~mL}$ of $1 \mathrm{M}$ sodium hydroxide $(1.0 \mathrm{M} \mathrm{NaOH})$ and vortexed for $10 \mathrm{~s}$. The absorbance of the aliquot was measured against prepared reagent blank at $510 \mathrm{~nm}$ and the total flavonoid content expressed as Catechin Equivalent (CE) $\mathrm{mg} / \mathrm{g}$ on dry mass (Kalita et al., 2013).

\subsection{Antioxidant activity}

Spectrophotometric DPPH, ABTS and FRAP methods were used to determine the total antioxidant activity. 
2.9 Determination of 2,2-diphenyl-1-picrylhydrazyl (DPPH) radical scavenging activity

DPPH scavenging activities of both the crude extract and solvent fractions were determined as described by Kortei et al. (2014). A stock solution $(1000 \mu \mathrm{g} / \mathrm{mL})$ was prepared by dissolving $10 \mathrm{mg}$ of each fraction in $10 \mathrm{~mL}$ of methanol. This was serially diluted to different concentrations $(0,10,50,100,250,500$, and $1000 \mu \mathrm{g} /$ $\mathrm{mL})$. A $50 \mu \mathrm{L}$ aliquot of each concentration was added to a mixture of $1000 \mu \mathrm{L}$ of $0.1 \mathrm{mM} \mathrm{DPPH}$ and $450 \mu \mathrm{L}$ of Tris buffer $\mathrm{pH} 7.4$ and incubated for 30 mins at room temperature. The absorbance was determined at $517 \mathrm{~nm}$ using a VERSAmax microplate reader. The experiment was repeated twice and means values recorded. The radical scavenging activity was calculated and expressed as a percentage of the control (free radical solution minus plant extract) using the following formula:

$$
\% \text { Scavenging }[\mathrm{DPPH}]=\left[\left(\mathrm{A}_{0}-\mathrm{A}_{1}\right) / \mathrm{A}_{0}\right] * 100
$$

Where $\mathrm{A}_{0}$ was the absorbance of the blank (in which the same volume of methanol was used in place of the sample) and $A_{1}$ was the absorbance in the presence of the samples or standard.

Each compound with antioxidant activity should be extracted in at least one of the fractionation solvents. Hence, after the initial screening using the DPPH assay, the crude extract was excluded in the subsequent antioxidant assays.

\subsection{Determination of 2,2'-azino-bis ethylbenzthiazoline-6-sulphonic) acid (ABTS) scavenging activity}

This was determined as per the protocol described by Re et al. (1999) with modification. A Stock solution of $(7 \mathrm{mM}, 10 \mathrm{~mL})$ ABTS and $(2.4 \mathrm{mM}, 10 \mathrm{~mL})$ potassium persulfate was prepared in distilled water and mixed to generate the ABTS free radical $\left(\mathrm{ABTS}^{\circ+}\right)$. The resulting solution was incubated in the dark at room temperature for $12 \mathrm{hrs}$ until the reaction was completed, by the observation of a constant absorbance. The $\mathrm{ABTS}^{\cdot+}$ solution $(1 \mathrm{~mL})$ was further diluted in $50 \mathrm{~mL}$ of methanol and the absorbance calibrated to 0.7 at $734 \mathrm{~nm}$. Dissolved extracts of $200 \mu \mathrm{L}$ (prepared from $100 \mu \mathrm{L}$ of extract dissolved in $900 \mu \mathrm{L}$ of hexane) and standard (prepared from a stock solution of $1000 \mu \mathrm{g} / \mathrm{mL}$ in methanol) was added to $800 \mu \mathrm{L}$ of the $\mathrm{ABTS}^{{ }^{++}}$solution, mixed and incubated at $30^{\circ} \mathrm{C}$ for 10 mins. The absorbance was read at $734 \mathrm{~nm}$. The radical scavenging capacity was compared with that of BHA and the inhibition was calculated as a percentage of the control sample (free radical solution minus plant extract) as:

$(\%)$ inhibition $=($ A control - A sample $) /$ A control $\times 100$
Where A control is the absorbance of $\mathrm{ABTS}^{++}$ solution and A sample is the absorbance of $\mathrm{ABTS}^{\circ+}$ sample (extract /standard). Negative control was prepared by replacing each fraction or standard with an equal volume of methanol.

\subsection{Ferric reducing antioxidant potential (FRAP) assay}

Ferric reducing power of fruits of Solanum (torvum, erianthum, and macrocarpon) extracts were determined using FRAP assay as per the protocol described by Luqman et al. (2012). This method is based on the reduction of colorless ferric complex ( $\mathrm{Fe}^{3+}$ tripyridyltriazine) to blue-colored ferrous complex ( $\mathrm{Fe}^{2+}$ tripyridyltriazine) by the action of electrondonating antioxidants at low $\mathrm{pH}$. The working FRAP reagent was prepared by mixing 10 volumes of $300 \mathrm{mM}$ acetate buffer, $\mathrm{pH} 3.6$, with 1 volume of $10 \mathrm{mM}$ TPTZ (2,4,6-tri(2-pyridyl)-s-triazine) in $40 \mathrm{mM} \mathrm{HCl}$ and with 1 volume of $20 \mathrm{mM}$ ferric chloride. All the required solutions were freshly prepared before their uses. $100 \mu \mathrm{L}$ of samples $(\mu \mathrm{L} / \mathrm{mL})$ was added to $3 \mathrm{~mL}$ of prepared FRAP reagent. The reaction mixture was incubated in a water bath for $30 \mathrm{mins}$ at $37^{\circ} \mathrm{C}$. Then, the absorbance of the samples was measured at $593 \mathrm{~nm}$. The difference between the absorbance of the sample and the absorbance of blank was calculated and used to calculate the FRAP value.

\subsection{Statistical analysis}

The experiment was carried out in duplicates and values were expressed as means and standard deviations. One- way analysis of variance (ANOVA) was done using IBM Statistical Package for Social sciences (SPSS) version 2.0. Means were separated using Duncans Multiple Range Test (DMRT), significance was denoted at $5 \%$ in all instances.

\section{Results}

\subsection{Sample extracts and percentage yields}

Table 1 shows the extraction yield of the dried and milled fruits/berries of Solanum (torvum, erianthum, and macrocarpon) using 70\% methanol. Methanol extracts of fruits of $S$. torvum at the 3 different ripening stages produced the highest yield as compared to $S$. erianthum and $S$. marcrocarpon. The methanol extract of the post matured stage of $S$. torvum recorded the highest percentage yield with $21.40 \%$ of all maturity stages of $S$. torvum. This was followed by the pre/early matured stage of $S$. erianthum with $11.40 \%$ yield and finally, the pre/early matured stage of $S$. macrocarpon had the thirdhighest yield. The percentage yield of Solanum (torvum, erianthum, and macrocarpon) at different maturity stages using methanol extract decreased in the following 
Table 1. Percentage yield of dried powdered fruits in methanol solvent

\begin{tabular}{lcccc}
\hline Sample ID & Mass of empty petri dish (g) & Mass of empty petri dish + extract (g) & Mass of extract (g) & Percentage yield (\%) \\
\hline $\mathrm{St}_{1}$ & 44.3 & 44.84 & 0.54 & 10.8 \\
$\mathrm{St}_{2}$ & 48.96 & 49.46 & 0.5 & 10 \\
$\mathrm{St}_{3}$ & 45.3 & 46.37 & 1.07 & 21.4 \\
$\mathrm{Se}_{1}$ & 41.96 & 42.53 & 0.57 & 11.4 \\
$\mathrm{Se}_{2}$ & 42.5 & 43.02 & 0.52 & 10.4 \\
$\mathrm{Se}_{3}$ & 42.01 & 42.32 & 0.31 & 6.2 \\
$\mathrm{Sm}_{1}$ & 42.69 & 43.26 & 0.57 & 11.4 \\
$\mathrm{Sm}_{2}$ & 41.96 & 42.24 & 0.28 & 5.6 \\
$\mathrm{Sm}_{3}$ & 40.08 & 40.35 & 0.27 & 5.4
\end{tabular}

order: late/post matured stage of $S$. torvum $\left(\mathrm{St}_{3}\right)>$ early/ pre matured stage of S.erianthum $\left(\mathrm{Se}_{1}\right)>$ early/pre matured stage of $S$. macrocarpon $\left(\mathrm{Sm}_{1}\right)>$ early/pre matured stage of S.torvum $\left(\mathrm{St}_{1}\right)>$ matured stage of $S$. erianthum $\left(\mathrm{Se}_{2}\right)>$ matured stage of $S$. torvum $\left(\mathrm{St}_{2}\right)>$ late/ post matured stage of $S$. erianthum $\left(\mathrm{Se}_{3}\right)>$ matured stage of $S$. macrocarpon $\left(\mathrm{Sm}_{2}\right)>$ late/post matured stage of $S$. macrocarpon $\left(\mathrm{Sm}_{3}\right)$.

\subsection{Evaluation of antioxidant activity}

In order to ascertain the antioxidant activity, the extracts (with methanol and ethanol) were screened using three different assays which included DPPH (1, 1diphenyl-2 picrylhydrazyl) radical scavenging activity, ABTS [(2,2-azinobis,3-ethylbenzothiazoline-6-sulfonic acid)] and Ferric Reducing Antioxidant Potential (FRAP). Results of DPPH are shown in Table 2. Methanol extracts recorded a range of $37.79 \pm 0.36$ $88.34 \pm 4.36$ for $S$. erianthum $\left(\mathrm{Se}_{3}, \mathrm{Se}_{1}\right)$. Generally, extraction with methanol was statistically different $(\mathrm{p}<0.05)$ among the various stages of $S$. torvum and $S$. erianthum. However, values obtained for $S$. macrocarpon were comparable $(\mathrm{p}>0.05)$.

Ethanol recorded a ranged of $6.97 \pm 2.09$ $39.53 \pm 1.74$ for $S$. macrocarpon $\left(\mathrm{Sm}_{3}\right)$ S. torvum $\left(\mathrm{St}_{2}\right)$. There were statistically significant differences $(\mathrm{p}<0.05)$

Table 2. DPPH radical scavenging activity of fruits of Solanum (torvum, erianthum and macrocarpon) extract

\begin{tabular}{ccc}
\hline Sample ID & $\begin{array}{c}\text { Methanolic Extraction } \\
(\%)\end{array}$ & $\begin{array}{c}\text { Ethanolic Extraction } \\
(\%)\end{array}$ \\
\hline $\mathrm{St}_{1}$ & $45.64 \pm 2.57^{\mathrm{c}}$ & $9.10 \pm 1.46^{\mathrm{a}}$ \\
$\mathrm{St}_{2}$ & $68.16 \pm 16.30^{\mathrm{d}}$ & $39.53 \pm 1.74^{\mathrm{c}}$ \\
$\mathrm{St}_{3}$ & $71.54 \pm 9.38^{\mathrm{c}}$ & $28.87 \pm 4.12^{\mathrm{b}}$ \\
$\mathrm{Se}_{1}$ & $88.34 \pm 4.36^{\mathrm{d}}$ & $28.68 \pm 1.46^{\mathrm{b}}$ \\
$\mathrm{Se}_{2}$ & $72.82 \pm 15.88^{\mathrm{c}}$ & $27.5 \mathrm{I} \pm 2.20^{\mathrm{b}}$ \\
$\mathrm{Se}_{3}$ & $37.79 \pm 0.36^{\mathrm{c}}$ & $25.77 \pm 2.04^{\mathrm{b}}$ \\
$\mathrm{Sm}_{1}$ & $60.93 \pm 13.42^{\mathrm{c}}$ & $29.06 \pm 0.58^{\mathrm{b}}$ \\
$\mathrm{Sm}_{2}$ & $78.34 \pm 0.63^{\mathrm{c}}$ & $18.79 \pm 2.92^{\mathrm{b}}$ \\
$\mathrm{Sm}_{3}$ & $57.53 \pm 9.58^{\mathrm{c}}$ & $6.97 \pm 2.09^{\mathrm{a}}$ \\
\hline
\end{tabular}

Values are means \pm SD of 3 replications. Means in a column with the same superscript are not significantly different $(\mathrm{p} \geq 0.05)$. observed among the different stages of $S$. torvum and $S$. macrocarpon while no significant differences $(\mathrm{p}>0.05)$ for S. macrocarpon.

There was a decreasing trend DPPH radical scavenging activity with the increasing maturity time of the fruits.

\subsection{2,2'-azino-bis (3-ethylbenzthiazoline-6-sulphonic) acid (ABTS) radical scavenging activity}

ABTS is used to measure the antioxidant capacities of food. In this assay, ABTS is converted to its radical cation by the addition of sodium persulfate. The ABTS radical cation is reactive towards most antioxidants including phenolics, thiols, and vitamin C. During this reaction the blue ABTS radical cation is converted back to its colorless neutral form. Results showed a methanol range of $16.66 \pm 7.40-47.49 \pm 15.27\left(\mathrm{Se}_{3}, \mathrm{St}_{2}\right)$ and showed a significant difference $(\mathrm{p}<0.05)$ in all maturity stages of all species while ethanol ranged between $1.61 \pm 0.64$ $20.60 \pm 0.18\left(\mathrm{Sm}_{3}, \mathrm{St}_{3}\right)$. All species showed significant differences $(\mathrm{p}<0.05)$ except for S. erianthum (Table 3$)$.

\subsection{Ferric reducing antioxidant power based on FRAP} assay

FRAP assay measures the reducing potential of an

Table 3. ABTS radical scavenging activity of extracts of Solanum (torvum, erianthum and macrocarpon) extract

\begin{tabular}{ccc}
\hline Sample ID & $\begin{array}{c}\text { Methanolic Extraction } \\
(\%)\end{array}$ & $\begin{array}{c}\text { Ethanolic Extraction } \\
(\%)\end{array}$ \\
\hline $\mathrm{St}_{1}$ & $37.22 \pm 12.53^{\mathrm{c}}$ & $6.14 \pm 0.32^{\mathrm{a}}$ \\
$\mathrm{St}_{2}$ & $47.49 \pm 15.27^{\mathrm{d}}$ & $12.08 \pm 7.29^{\mathrm{b}}$ \\
$\mathrm{St}_{3}$ & $45.64 \pm 3.93^{\mathrm{d}}$ & $20.60 \pm 0.18^{\mathrm{b}}$ \\
$\mathrm{Se}_{1}$ & $40.00 \pm 21.79^{\mathrm{d}}$ & $14.45 \pm 1.86^{\mathrm{b}}$ \\
$\mathrm{Se}_{2}$ & $46.38 \pm 8.17^{\mathrm{d}}$ & $15.42 \pm 3.27^{\mathrm{b}}$ \\
$\mathrm{Se}_{3}$ & $16.66 \pm 7.40^{\mathrm{b}}$ & $18.23 \pm 0.49^{\mathrm{b}}$ \\
$\mathrm{Sm}_{1}$ & $47.22 \pm 17.97^{\mathrm{d}}$ & $17.47 \pm 2.33^{\mathrm{b}}$ \\
$\mathrm{Sm}_{2}$ & $37.49 \pm 15.43^{\mathrm{c}}$ & $10.89 \pm 6.16^{\mathrm{b}}$ \\
$\mathrm{Sm}_{3}$ & $35.27 \pm 18.33^{\mathrm{c}}$ & $1.61 \pm 0.64^{\mathrm{a}}$ \\
\hline
\end{tabular}

Values are means \pm SD of 3 replications. Means in a column with the same superscript are not significantly different $(\mathrm{p} \geq 0.05)$.

C 2020 The Authors. Published by Rynnye Lyan Resources 
antioxidant reacting with a ferric tripyridyl triazine $\left(\mathrm{Fe}^{2+}-\right.$ TPTZ). At a low $\mathrm{pH}$ of about 3.6, the reduction of $\mathrm{Fe} 3+-$ TPTZ complex to blue colored $\mathrm{Fe}^{2+}$-TPTZ takes place which has an absorbance at $593 \mathrm{~nm}$. At equal concentrations of different extraction solvents, there was an indication of the difference in the ferric reduction activity of the extracts. Comparing the different extraction solvents, ethanol recorded the highest solvent with the ferric reducing activity was followed by methanol. Extraction with ethanol the species that recorded the highest antioxidant activity of $0.607 \pm 0.00$ using the FRAP assay was the post/late matured stage of $S$. macrocarpon followed by the pre/early matured stage of $S$. torvum $(0.162 \pm 0.00)$ while the pre/early matured stage of $S$. macrocarpon produced the least antioxidant activity of $0.023 \pm 0.00$. Also comparing the results for methanolic extraction, it was noted that the matured stage of the fruits of $S$. erianthum produced the highest antioxidant activity of $0.257 \pm 0.00$ followed by the late/ post matured stage of the same $S$. erianthum $(0.252 \pm 0.00)$. The species that recorded the third-highest value was the pre/early matured stage of $S$. torvum $(0.230 \pm 0.00)$ with the matured stage of the same $S$. torvum $(0.075 \pm 0.00)$ recording the lowest or least value. Table 4 shows the reducing power activity of Solanum (torvum, erianthum, and macrocarpon) at different maturity stages using different extraction solvents. Ferric reducing the power of extracts did not vary significantly among maturity/ripening stages the solvent used for extraction. The highest ferric reducing power of $0.607 \pm 0.00$ was recorded by the ethanol extract of the post/late matured stage of $S$. macrocarpon. It was also observed that for $S$. torvum, the ferric reducing activity was not consistent as berries matured but activity varied significantly depending on the maturity stage for both ethanol and methanol extraction. Subsequently, with $S$. erianthum, ferric reducing activity did not show

Table 4. Ferric reducing antioxidant potential of extracts of Solanum (torvum, erianthum and macrocarpon) against ascorbic acid (positive control)

\begin{tabular}{cccc}
\hline Sample ID & $\begin{array}{c}\text { Methanolic } \\
\text { Extraction (\%) }\end{array}$ & $\begin{array}{c}\text { Ethanolic } \\
\text { Extraction (\%) }\end{array}$ & $\begin{array}{c}\text { Ascorbic Acid } \\
(\%)\end{array}$ \\
\hline $\mathrm{St}_{1}$ & $0.230 \pm 0.00^{\mathrm{d}}$ & $0.162 \pm 0.00^{\mathrm{c}}$ & \\
$\mathrm{St}_{2}$ & $0.075 \pm 0.00^{\mathrm{b}}$ & $0.061 \pm 0.00^{\mathrm{a}}$ & \\
$\mathrm{St}_{3}$ & $0.126 \pm 0.00^{\mathrm{c}}$ & $0.118 \pm 0.00^{\mathrm{b}}$ & \\
$\mathrm{Se}_{1}$ & $0.172 \pm 0.00^{\mathrm{b}}$ & $0.045 \pm 0.00^{\mathrm{a}}$ & \\
$\mathrm{Se}_{2}$ & $0.257 \pm 0.00^{\mathrm{c}}$ & $0.141 \pm 0.00^{\mathrm{b}}$ & 2 \\
$\mathrm{Se}_{3}$ & $0.252 \pm 0.00^{\mathrm{c}}$ & $0.136 \pm 0.00^{\mathrm{b}}$ & \\
$\mathrm{Sm}_{1}$ & $0.092 \pm 0.00^{\mathrm{a}}$ & $0.023 \pm 0.00^{\mathrm{a}}$ & \\
$\mathrm{Sm}_{2}$ & $0.202 \pm 0.00^{\mathrm{c}}$ & $0.152 \pm 0.00^{\mathrm{b}}$ & \\
$\mathrm{Sm}_{3}$ & $0.161 \pm 0.00^{\mathrm{b}}$ & $0.607 \pm 0.00^{\mathrm{d}}$ & \\
\hline
\end{tabular}

Values are means \pm SD of 3 replications. Means in a column with the same superscript are not significantly different $(\mathrm{p} \geq 0.05)$. consistency in increase as fruits/berries matured but rather activity reduced as the fruits/berries are at the post/late maturity stage for both methanol and ethanol extracts. For both solvents, the matured stages recorded the highest values $(0.257 \pm 0.00, \quad 0.141 \pm 0.00)$. Accordingly, a similar trend was also observed in $S$. macrocarpon. Ferric reducing activity of $S$. macrocarpon showed significant variation $(\mathrm{p}<0.05)$ among the maturity stages. There was an observed irregular pattern of distribution of FRAP values as maturity progressed among the different species of Solanum.

\subsection{Total phenolic and flavonoid content}

\subsubsection{Total phenolic content}

The total phenolic content of Solanum (torvum, erianthum, and macrocarpon) extracts of both methanol and ethanol solvents was measured and expressed as mg of gallic acid (standard phenolic compound) per gram dry weight of extract ( $\mu \mathrm{L}$ GAE/10 $\mu \mathrm{L}$ ) (Table 5). Using methanol as the extraction solvent had the highest phenolic content. The ethanol extract of matured stage of $S$. macrocarpon $(25.28 \pm 0.25 \mu \mathrm{L} \mathrm{GAE} / 10 \mu \mathrm{L})$ recorded the highest followed by the post matured stage of the same $S$. macrocarpon $(23.86 \pm 0.19 \mu \mathrm{L}$ GAE $/ 10 \mu \mathrm{L})$ and pre/early matured stage of $S$. torvum recorded the least $(13.19 \pm 0.01 \mu \mathrm{L} \mathrm{GAE} / 10 \mu \mathrm{L})$. With the methanol extract, the matured stage of $S$. erianthum $(40.62 \pm 0.00 \mu \mathrm{L}$ $\mathrm{GAE} / 10 \mu \mathrm{L}$ ) recorded the highest phenolic content followed by the pre/early matured stage of $S$. macrocarpon $(40.61 \pm 0.00 \mu \mathrm{L} \mathrm{GAE} / 10 \mu \mathrm{L})$ and the post/ late matured stage of $S$. torvum $(16.97 \pm 0.03 \mu \mathrm{L}$ GAE/10 $\mu \mathrm{L}$ ) recorded the least value.

Table 5. Total phenolic content of extracts of Solanum (torvum, erianthum and macrocarpon) extract

\begin{tabular}{ccc}
\hline Sample ID & $\begin{array}{c}\text { Methanolic Extraction } \\
(\mu \mathrm{L} \text { GAE } / 10 \mu \mathrm{L})\end{array}$ & $\begin{array}{c}\text { Ethanolic Extraction } \\
(\mu \mathrm{L} \text { GAE } / 10 \mu \mathrm{L})\end{array}$ \\
\hline $\mathrm{St}_{1}$ & $18.09 \pm 0.00^{\mathrm{b}}$ & $13.19 \pm 0.01^{\mathrm{a}}$ \\
$\mathrm{St}_{2}$ & $19.70 \pm 0.00^{\mathrm{b}}$ & $14.42 \pm 0.14^{\mathrm{a}}$ \\
$\mathrm{St}_{3}$ & $16.97 \pm 0.03^{\mathrm{b}}$ & $13.29 \pm 0.15^{\mathrm{a}}$ \\
$\mathrm{Se}_{1}$ & $26.95 \pm 0.00^{\mathrm{c}}$ & $16.91 \pm 0.10^{\mathrm{b}}$ \\
$\mathrm{Se}_{2}$ & $40.62 \pm 0.00^{\mathrm{d}}$ & $16.95 \pm 0.07^{\mathrm{b}}$ \\
$\mathrm{Se}_{3}$ & $29.94 \pm 0.07^{\mathrm{c}}$ & $22.69 \pm 0.19^{\mathrm{c}}$ \\
$\mathrm{Sm}_{1}$ & $40.61 \pm 0.00^{\mathrm{d}}$ & $23.51 \pm 0.37^{\mathrm{c}}$ \\
$\mathrm{Sm}_{2}$ & $22.15 \pm 0.65^{\mathrm{c}}$ & $25.28 \pm 0.25^{\mathrm{c}}$ \\
$\mathrm{Sm}_{3}$ & $26.05 \pm 0.00^{\mathrm{c}}$ & $23.86 \pm 0.19^{\mathrm{c}}$ \\
\hline
\end{tabular}

Values are means \pm SD of 3 replications. Means in a column with the same superscript are not significantly different $(\mathrm{p} \geq 0.05)$.

\subsubsection{Total flavonoids content}

The total flavonoid content of the crude extract and various fractions was measured and expressed as $\mathrm{mg}$ of quercetin (standard flavonoid compound) per gram dry weight of the extract. Range of values recorded for 
methanol was $96.25 \pm 0.36-434.55 \pm 0.31 \mu \mathrm{L} \mathrm{CE} / 10 \mu \mathrm{L}$ $\left(\mathrm{St}_{1}, \mathrm{Sm}_{3}\right.$, and $\left.\mathrm{Se}_{3}\right) . S$. erianthum produced the greatest quantity of flavonoids which was significantly $(\mathrm{p}<0.05)$ different from all the methanolic extracts. For ethanol, a range of $109.54 \pm 0.30-784.54 \pm 0.30 \mu \mathrm{L} \mathrm{CE} / 10 \mu \mathrm{L}\left(\mathrm{St}_{1}\right.$, $\mathrm{Sm}_{3}$, and $\mathrm{Se}_{2}$ ). Generally, greater quantities of ethanolic extracts $(>100 \mu \mathrm{L} \mathrm{CE} / 10 \mu \mathrm{L})$ of the flavonoids were obtained in this study with $S$. erianthum producing the maximum (Table 6).

\subsection{Mineral composition}

The elemental mineral composition (iron, potassium and magnesium content) of dried and milled fruits/ berries of Solanum (torvum, erianthum, and macrocarpon) are presented in Table 7 . From the table, it was observed that the Post/late matured stage of $S$. torvum recorded the highest iron content of $11.55 \mathrm{mg} / \mathrm{kg}$ followed by the matured stage of the same $S$. torvum $(11.21 \mathrm{mg} / \mathrm{kg})$. There was no significant difference $(p>0.05)$ between late/post matured and matured stages. However, the pre/early matured stage of $S$. torvum recorded the least iron content of $6.32 \mathrm{mg} / \mathrm{kg}$ and was significantly $(\mathrm{p}<0.05)$ lower. With magnesium, the recorded range of values was 24.88 $\pm 0.11-32.46 \pm 0.04$ $\mathrm{mg} / \mathrm{kg}$ for $\mathrm{St}_{1}$ and $\mathrm{Se}_{3}$ respectively. There were generally statistical differences $(\mathrm{p}<0.05)$ observed. $S$. torvum recorded a generally low level of $\mathrm{Mg}(24-26 \mathrm{mg} / \mathrm{kg})$. Lastly, sodium recorded a range of $11.50 \pm 0.04$ $41.82 \pm 0.16 \mathrm{mg} / \mathrm{kg}$ for $\mathrm{Sm}_{3}$ and $\mathrm{Se}_{2}$. Notably, the results showed significant differences $(p<0.05)$ between all samples analyzed (Table 7).

\section{Discussion}

All over the world, plants of the family Solanaceae have been employed for their edible and pharmaceutical benefits. In Ghana, locals depend heavily on the leaves and fruits/berries of most Solanum species for their

Table 6. Total flavanoid content of extracts of Solanum (torvum, erianthum and macrocarpon) extract

\begin{tabular}{ccc}
\hline Sample ID & $\begin{array}{c}\text { Methanolic Extraction } \\
(\mu \mathrm{L} \mathrm{CE} / 10 \mu \mathrm{L})\end{array}$ & $\begin{array}{c}\text { Ethanolic Extraction } \\
(\mu \mathrm{L} \mathrm{CE} / 10 \mu \mathrm{L})\end{array}$ \\
\hline $\mathrm{St}_{1}$ & $96.25 \pm 0.36^{\mathrm{a}}$ & $109.54 \pm 0.30^{\mathrm{b}}$ \\
$\mathrm{St}_{2}$ & $247.39 \pm 0.03^{\mathrm{b}}$ & $434.22 \pm 0.15^{\mathrm{c}}$ \\
$\mathrm{St}_{3}$ & $52.33 \pm 0.46^{\mathrm{a}}$ & $154.60 \pm 0.38^{\mathrm{b}}$ \\
$\mathrm{Se}_{1}$ & $134.51 \pm 0.26^{\mathrm{b}}$ & $426.28 \pm 0.40^{\mathrm{c}}$ \\
$\mathrm{Se}_{2}$ & $114.22 \pm 0.14^{\mathrm{b}}$ & $784.54 \pm 0.30^{\mathrm{d}}$ \\
$\mathrm{Se}_{3}$ & $434.55 \pm 0.31^{\mathrm{c}}$ & $286.16 \pm 0.22^{\mathrm{b}}$ \\
$\mathrm{Sm}_{1}$ & $134.49 \pm 0.38^{\mathrm{b}}$ & $479.51 \pm 0.26^{\mathrm{c}}$ \\
$\mathrm{Sm}_{2}$ & $62.29 \pm 0.38^{\mathrm{a}}$ & $472.63 \pm 0.04^{\mathrm{c}}$ \\
$\mathrm{Sm}_{3}$ & $96.25 \pm 0.36^{\mathrm{a}}$ & $109.54 \pm 0.30^{\mathrm{b}}$ \\
\hline
\end{tabular}

Values are means \pm SD of 3 replications. Means in a column with the same superscript are not significantly different ( $\mathrm{p} \geq 0.05$ ). mineral and antioxidant supplementations. Antioxidants are protective substances that protect the body's cells against the effects of free radicals and some naturally occurring antioxidants include flavonoids, tannins, phenols, and lignans-based foods are the best sources of antioxidants. Extraction is the main process by which bioactive compounds may be obtained from biomass materials. The objective of the extraction process is to maximize the number of target compounds and obtain the highest biological activity of these extracts (Truong et al., 2019). The extraction yield and biological activity of the resulting extract are not only affected by the extraction technique but also by the extraction solvent (Pour et al., 2011).

Variations observed for the extracts of the different samples could be attributed to differences in the polarity of the extraction solvents which might have caused a wide variation in the level of bioactive compounds in the extracts (Truong et al., 2019).A higher extraction yield was observed in the methanolic extract as compared to that of the ethanol extract (data not shown) indicating that the extraction efficiency favors the highly polar solvent which is methanol than ethanol which is less polar.

Antioxidant capacity is an important parameter that is used to establish the health benefits of food and food products and represent the ability to inhibit the process of oxidation (Bhandari and Lee, 2016). It is a very beneficial and desirable property of foods as oxidation by free radicals plays a major role in the pathogenesis of many human diseases as well as aging. Different Solanum species exhibit variation in their antioxidant activity of which $S$. torvum, $S$. erianthum, and $S$. macrocarpon are of no exception. This could be due to the presence of several natural compounds such as tannins, saponins, lycopene, phenolic compounds, flavonoids, etc. (Martínez-Valverde et al., 2002). The

Table 7. Mineral content of dried fruits/berries of Solanum (torvum, erianthum and macrocarpon)

\begin{tabular}{cccc}
\hline Sample ID & $\mathrm{Fe}(\mathrm{mg} / \mathrm{kg})$ & $\mathrm{Mg}(\mathrm{mg} / \mathrm{kg})$ & $\mathrm{Na}(\mathrm{mg} / \mathrm{kg})$ \\
\hline $\mathrm{St}_{1}$ & $6.32 \pm 0.05^{\mathrm{b}}$ & $24.88 \pm 0.11^{\mathrm{b}}$ & $15.33 \pm 0.01^{\mathrm{g}}$ \\
$\mathrm{St}_{2}$ & $11.21 \pm 0.02^{\mathrm{e}}$ & $24.93 \pm 0.04^{\mathrm{b}}$ & $34.32 \pm 0.03^{\mathrm{a}}$ \\
$\mathrm{St}_{3}$ & $11.55 \pm 0.07^{\mathrm{e}}$ & $25.60 \pm 0.14^{\mathrm{c}}$ & $39.27 \pm 0.56^{\mathrm{c}}$ \\
$\mathrm{Se}_{1}$ & $6.33 \pm 0.03^{\mathrm{b}}$ & $31.22 \pm 0.17^{\mathrm{f}}$ & $56.91 \pm 0.04^{\mathrm{e}}$ \\
$\mathrm{Se}_{2}$ & $4.87 \pm 0.03^{\mathrm{a}}$ & $23.23 \pm 0.04^{\mathrm{a}}$ & $41.82 \pm 0.16^{\mathrm{d}}$ \\
$\mathrm{Se}_{3}$ & $10.65 \pm 0.06^{\mathrm{d}}$ & $32.46 \pm 0.04^{\mathrm{g}}$ & $36.62 \pm 0.09^{\mathrm{b}}$ \\
$\mathrm{Sm}_{1}$ & $8.55 \pm 0.06^{\mathrm{c}}$ & $29.58 \pm 0.12^{\mathrm{d}}$ & $35.03 \pm 0.09^{\mathrm{a}}$ \\
$\mathrm{Sm}_{2}$ & $10.09 \pm 0.00^{\mathrm{d}}$ & $30.66 \pm 0.23^{\mathrm{e}}$ & $34.82 \pm 0.02^{\mathrm{a}}$ \\
$\mathrm{Sm}_{3}$ & $8.35 \pm 0.06^{\mathrm{c}}$ & $30.83 \pm 0.02^{\mathrm{e}}$ & $11.50 \pm 0.04^{\mathrm{f}}$ \\
\hline
\end{tabular}

Values are means \pm SD of 3 replications. Means in a column with the same superscript are not significantly different $(\mathrm{p} \geq 0.05)$. 
DPPH assay is known to be a rapid, simple and inexpensive way to determine the antioxidant activity of food and food products by testing their ability to act as free radical scavengers or hydrogen donors (Bhandari and Lee, 2016).

DPPH is a nitrogen-centered free radical; hence any compound that can scavenge a significant amount of DPPH may be useful in reducing the levels of other reactive nitrogen species in living cells (Tettey et al., 2014). The basis of this method is that antioxidants react with the stable free radical (DPPH) and convert it to 2,2diphenyl-1-picrylhydrazyl, which is accompanied by a color change from purple to yellow (Bhandari and Lee, 2016). Among the extracts tested, the methanolic extract was the most potent in terms of values of DPPH scavenging activity. Remarkably, methanolic extract of all samples exhibited a two-fold higher DPPH scavenging activity than that of ethanolic extracts. This could be as attributed to the reason that this extract contains the highest level of phenolics, flavonoids, alkaloids, and terpenoid compounds, etc. Those compounds possess powerful antioxidant activity and subsequently protect the human body against oxidative damage. Also, from the results, it was evident that DPPH radical scavenging activity of species varied significantly at different maturity/ripening stages. It was obvious from the table that the pre/early matured stage of $S$. erianthum recorded the highest activity followed by the matured stage of $S$. macrocarpon and finally the late/post matured stage of $S$. torvum. The mean yield of ethanol extract of methanol was different from the findings of (Batra and Sharma, 2013). This could be attributed to the presence of other compounds like saponins, tannins, and alkaloids which increases or decreases as fruits/berries mature.

$\mathrm{ABTS}^{\circ+}$ is a protonated free radical and hence was used in this study to examine the capacity of the leaf extracts to reduce the positive charged radical in solution. This assay was also included in this study because $\mathrm{ABTS}^{\circ+}$ is sensitive over a broad range, from highly potent to very weak antioxidants, the latter which may not be detected by the DPPH assay. Compounds with one $\mathrm{OH}$ group in the aromatic ring which are found inactive towards the DPPH radical are significantly active towards $\mathrm{ABTS}^{\circ+}$ (Nenadis and Tsimidou, 2002). It was observed from Table 4 that the $\mathrm{ABTS}^{\circ+}$ scavenging activity varied significantly with both methanol and ethanol extraction. Values for methanolic extract recorded higher values than that of the ethanolic extract and values also showed variation at different maturity stages. For $S$. macrocarpon, it was observed that $\mathrm{ABTS}^{\circ}$ scavenging activity for both ethanol and methanol increased as fruit/berries matured from one stage to another. Subsequently, for S. torvum and erianthum (methanol), activity did not show consistency from one maturity stage to another.

The assessment of antioxidant activity to reduce iron represents the ability of a substance to transfer an electron or hydrogen atom from another substance to and an antioxidant ability to reduce the oxidized intermediates during the peroxidation process (GómezOrdóñez et al., 2012). All the variations were different from the findings of Gandhiappan and Rengasamy, (2012) and could be attributed to the presence of phenolic compounds that may act by donating the electrons and acting with free radicals to convert them to more stable products and terminate radical chain reaction (Du et al., 2012).

Phenolic compounds are very important metabolites and perform and possess various biological functions of which the most important is an antioxidant activity associated with the reduction of cancer and cardiovascular diseases (Toor and Savage, 2005). Phenolic compounds contribute about $60-70 \%$ of the antioxidant activity in Solanum species. In this study, the total phenolic content in the extract of the three Solanum species showed independent patterns at different physiological maturity stages. Phenolic content showed variation in increment as fruits/ berries got to different maturity stages. The results of this study disagreed with the research findings of Waghulde et al. (2011) who reported values of $9.953 \mathrm{mg} \mathrm{GAE} / 100 \mathrm{~g}$ and 7.890 GAE/100 g respectively for methanol and ethanol extracts of $S$. torvum phenol content. Such fluctuations in the total phenolic content could be mainly due to the differences in several factors such as temperature, sunlight, rainfall and compounds such as tannin, saponins, etc. that contributed to the variations. However additional studies are needed for further clarification.

Flavonoids are secondary plant metabolites that possess strong antioxidant, an anti-proliferative and antibacterial activity which are known to increase with plant stress (Panche et al., 2016). They play an important role in the control of plant resources to biotic and abiotic stress. In human nutrition, flavonoids are considered as potential health-promoting substances due to their antioxidative, anti-cancer, and cardiovascular protective effects. They also have anti-microbial, antiinflammatory, anti-aging and neuroprotective effects (Ginwala et al., 2019). In this present study, the flavonoid content of both methanol and ethanol extract as seen in Table 4 indicated that there was a significant variation in flavonoid at the different maturity stages and values for both methanol and ethanol extract were significantly different. It was observed that $S$. torvum showed inconsistency in flavonoid content as the fruits/ 
berries moved from one physiological maturity stage to another. Finally, it was interesting to note that flavonoid content was directly proportional to the maturity stage. Variation in flavonoid content in fruits is strongly influenced by extrinsic factors such as fruit type and growth, season, climate, degree of ripeness, food preparation, and processing as suggested by Lakenbrink et al. (2000) and Panche et al. (2016).

Overproduction of free radicals i.e oxidative as well as nitrosative stress during hypercholesterolemia is a major root reason for the pathophysiology of atherosclerosis and other related cardiovascular diseases (Lahera et al., 2007). The importance of dietary phenolic compounds as highlighted by Chiu et al. (2018) in combating cardiovascular diseases cannot be overemphasized. Consumption of Solanum spp. is very beneficial for human health as it has been proven to possess adequate amounts of essential phytochemicals.

\subsection{Mineral composition}

Minerals are vital elements required for the normal growth and maintenance of the body. They are also important constituents of the human diet as they serve as co-factors for many physiological and metabolic processes (Arivalagan et al., 2013). Deficiencies of micro-minerals are a major global health problem. More than 2 billion peoples in the world today are estimated to be deficient in key minerals particularly minerals (Arivalagan et al., 2013). The significance of these elements cannot be overemphasized.

Iron is an indispensable mineral in the body that is involved in processes such as hemoglobin production and oxygenation of red blood cells, digestion and circulation among many others are carried out in the human body as suggested by Agyei-Poku (2018). For its function in hemoglobin production, it's mostly required in the diet of pregnant women, nursing mothers, infants, convulsing patients and the elderly to prevent anemia and other related diseases (Bamishaiye et al., 2011). The results indicated that iron was the least concentrated of all the minerals analyzed in the samples. Also, the iron content of both $S$. erianthum and macrocarpon did not follow a similar trend as fruits/berries moved from one maturity stage to another. Dissimilar results were reported by Akoto et al. (2015), Mahapatra et al. (2012) and Otu et al. (2017). However, higher values were recorded by Eletta et al. (2017) and Sam et al. (2012). The differences in iron content among maturity stages of different species could be attributed to factors such as type of fruit, degree of ripeness climate, etc and also the presence of other phytochemicals.

Magnesium is an important co-factor of many regulatory enzymes, particularly the kinase, and is fundamental in the energy transfer reaction involving high energy compounds like ATP and creatinine phosphate and thus muscle contraction (Brewer and Wallimann, 2000). Magnesium is involved in enzymatic reaction of carbohydrate catabolism e.g. glycolysis. Its deficiency in man, however, may lead to severe diarrhea, migraines, hypertension, cardiomyopathy, arteriosclerosis and stroke (Bamishaiye, 2011). Values obtained in this study disagreed with values reported in a study by Agyei-Poku (2018) of a range of 1365-5550 $\mathrm{mg} / \mathrm{Kg}$. This observation indicated that magnesium concentrations were not directly proportional to the maturity stages but rather this variation could be attributed to different factors that affect magnesium concentrations in fruits. The values obtained in these studies are low to meet the Recommended Daily Allowance (RDA) of $400 \mathrm{mg} / 100 \mathrm{~mL}$ for men, women of 19 to 39 years old (Institute of Medicine (US) Standing Committee on the Scientifice Evaluation of Dietary Reference Intakes, 1997).

Sodium helps in the transmission of nerve impulses and brings about an osmotic balance of the cells in the living tissue.

\section{Conclusion}

In conclusion, the present study revealed that the levels of antioxidants, total phenolics and flavonoids are significantly affected by both the physiological maturity stage and extraction solvents. It was clear that all methanolic extract showed significant variations with high values in antioxidants which included the DPPH scavenging activity, the $\mathrm{ABTS}^{\cdot+}$ scavenging activity, the ferric reduction power assay, the total phenolics, and the flavonoid content. It was also interesting to note that most values for all these phytochemical constituents varied drastically as the physiological maturity stage varied. In general, some values reduced down the stages that are from the early/pre matured stage to the post/late matured stage and others increased down the stages. Some species did not also show consistency in increment or decrement of values down thee physiological maturity stages. Also, the three species contained significant amounts of the minerals iron, magnesium, and sodium at different maturity stages. Some of the values obtained were lower when compared with the Standard Dietary Allowance (RDA) and others too were higher.

\section{Acknowledgments}

The authors would like to acknowledge the technical staff of both the Department of Nutrition and Dietetics, School of Allied Health Sciences as well as the 
Department of Biomedical Sciences, School of Basic and Biomedical Sciences of the University of Health and Allied Sciences, Ho, Ghana for providing the materials and reagents to undertake the antioxidant analysis. Also, to the Department of Chemistry, Ghana Atomic Energy Commission (GAEC), Kwabenya- Accra for undertaking the elemental mineral analysis.

\section{References}

Agyei-Poku, B. (2018). The Effect of Pre-Treatment and Oven Drying Temperatures on the Nutritional, AntiNutritional Values and Colour Properties of the Fruits of Solanum Torvum. Ghana: Kwame Nkrumah University of Science and Technology, $\mathrm{PhD}$ thesis.

Akoto, O., Borquaye, L.S., Howard, A.S. and Konwuruk, N. (2015). Nutritional and mineral composition of the fruits of Solanum torvum from Ghana. International Journal of Chemical and Biomoleuclar Science, 1, 222-226.

AOAC. (2000). Official methods of analysis. Gaithersburg,USA: AOAC

Arivalagan, M., Bhardwaj, R., Gangopadhyay, K.K., Prasad, T.V. and Sarkar, S.K. (2013). Mineral composition and their genetic variability analysis in eggplant (Solanum melongena L.) germplasm. Journal of Applied Botany and Food Quality, 86(1), 99-103.

Babalola, O., Agbi, J., Badiora, A. and Areola, O. (2016). Protective Effects of Solanum erianthum D. Don Leaf Extract on Lead-Induced Toxicity in Adult Wistar Rats. Journal of Applied Pharmaceutical Science, 6(10), 113-123. https://doi.org/10.7324/ JAPS.2016.601016

Bamishaiye, E., Olayemi, F. and Bamishaiye, O. (2011). Effects of boiling time on mineral and vitamin $\mathrm{C}$ content of three varieties of Hibiscus sabdriffa drink in Nigeria. World Journal of Agricultural Sciences, 7 (1), 62-67.

Batra, P. and Sharma, A.K. (2013). Anti-cancer potential of flavonoids: recent trends and future perspectives. 3 Biotech, 3(6), 439-459. https://doi.org/10.1007/ s13205-013-0117-5

Bhalodia, N.R., Acharya, R.N. and Shukla, V. (2011). Evaluation of in vitro antioxidant activity of flowers of Cassia fistula Linn. Free Radicals and Antioxidants, 1(1), 68-76. https://doi.org/10.5530/ ax.2011.1.11

Bhandari, S.R. and Lee, J.G. (2016). Ripening-dependent changes in antioxidants, color attributes, and antioxidant activity of seven tomato (Solanum lycopersicum L.) cultivars. Journal of Analytical Methods in Chemistry, 2016, 5498618 https:// doi.org/10.1155/2016/5498618

Brewer, G.J. and Wallimann, T.W. (2000). Protective effect of the energy precursor creatine against toxicity of glutamate and $\beta$-amyloid in rat hippocampal neurons. Journal of Neurochemistry, 74 (5), 1968-1978. https://doi.org/10.1046/j.14714159.2000.0741968.x

Chiu, Y.-J., Chou, S.-C., Chiu, C.-S., Kao, C.-P., Wu, K. -C., Chen, C.-J., Tsai, J.-C. and Peng, W.-H. (2018). Hepatoprotective effect of the ethanol extract of Polygonum orientale on carbon tetrachlorideinduced acute liver injury in mice. Journal of Food and Drug Analysis, 26(1), 369-379. https:// doi.org/10.1016/j.jfda.2017.04.007

Du, B., He, B.-J., Shi, P.-B., Li, F.-Y., Li, J. and Zhu, F.M. (2012). Phenolic content and antioxidant activity of wine grapes and table grapes. Journal of Medicinal Plants Research, 6(17), 3381-3387. https://doi.org/10.5897/JMPR12.238

Eletta, O., Orimolade, B., Oluwaniyi, O. and Dosumu, O. (2017). Evaluation of proximate and antioxidant activities of Ethiopian eggplant (Solanum aethiopicum L) and Gboma Eggplant (Solanum macrocarpon L). Journal of Applied Sciences and Environmental Management, 21(5), 967-972. https:// doi.org/10.4314/jasem.v21i5.25

Gandhiappan, J. and Rengasamy, R. (2012). Comparative study on antioxidant activity of different species of Solanaceae family. Advances in Applied Science Research, 3(3), 1538-1544.

Ginwala, R., Bhavsar, R., Chigbu, D.G.I., Jain, P. and Khan, Z.K. (2019). Potential role of flavonoids in treating chronic inflammatory diseases with a special focus on the anti-inflammatory activity of apigenin. Antioxidants, 8(2), 35. https://doi.org/10.3390/ antiox 8020035

Gómez-Ordóñez, E., Jiménez-Escrig, A. and Rupérez, P. (2012). Effect of the red seaweed Mastocarpus stellatus intake on lipid metabolism and antioxidant status in healthy Wistar rats. Food chemistry, 135(2), 806-811.

https://doi.org/10.1016/ j.foodchem.2012.04.138

Haliński, Ł.P., Topolewska, A., Rynkowska, A., Mika, A., Urasińska, M., Czerski, M. and Stepnowski, P. (2019). Impact of plant domestication on selected nutrient and anti-nutrient compounds in Solanaceae with edible leaves (Solanum spp.). Genetic resources and crop evolution, 66(1), 89-103. https:// doi.org/10.1007/s10722-018-0699-1 
Institute of Medicine (US) Standing Committee on the Scientifice Evaluation of Dietary Reference Intakes. (1997). Dietary Reference Intakes for Calcium, Phosphorus, Magnesium, Vitamin D, and Fluoride. Washington, D.C., USA: National Academies Press.

Kalita, P., Tapan, B.K., Pal, T.K. and Kalita, R. (2013). Estimation of total flavonoids content (TFC) and anti oxidant activities of methanolic whole plant extract of Biophytum sensitivum Linn. Journal of Drug delivery and Therapeutics, 3(4), 33-37. https:// doi.org/10.22270/jddt.v3i4.546

Kortei, N.K., Odamtten, G.T., Obodai, M., Appiah, V., Akuamoa, F., Adu-Bobi, A.K., Annan, S.N.Y., Armah, J.N.O. and Acquah, S.A. (2014). Evaluating the effect of gamma radiation on the total phenolic content, flavonoids, and antioxidant activity of dried Pleurotus ostreatus ((Jacq. ex. Fr) Kummer) stored in packaging materials. Advances in Pharmaceutics, 2014, 262807. https://doi.org/10.1155/2014/262807

Kuffuor, G.A., Amoateng, P. and Andey, T.A. (2011). Immunomodulatory and Erythropoietic Effects of Aqueous Extract of the Fruits of Solanum Torvum Swartz (Solanaceae). Pharmacognosy Research 3 (2), 130-34. https://doi.org/10.4103/09748490.81961

Lahera, V., Goicoechea, M., Garcia de Vinuesa, S., Miana, M., Heras, N.D.L., Cachofeiro, V. and Luno, J. (2007). Endothelial dysfunction, oxidative stress and inflammation in atherosclerosis: beneficial effects of statins. Current Medicinal Chemistry, 14 (2), 243-248. https:// doi.org/10.2174/092986707779313381

Lakenbrink, C., Lapczynski, S., Maiwald, B. and Engelhardt, U.H. (2000). Flavonoids and other polyphenols in consumer brews of tea and other caffeinated beverages. Journal of Agricultural and Food Chemistry, 48(7), 2848-2852. https:// doi.org/10.1021/jf9908042

Luqman, S., Srivastava, S., Kumar, R., Maurya, A.K. and Chanda, D. (2012). Experimental assessment of Moringa oleifera leaf and fruit for its antistress, antioxidant, and scavenging potential using in vitro and in vivo assays. Evidence-Based Complementary and Alternative Medicine, 2012, 519084 https:// doi.org/10.1155/2012/519084

Mahapatra, A.K., Mishra, S., Basak, U.C. and Panda, P.C. (2012). Nutrient analysis of some selected wild edible fruits of deciduous forests of India: an explorative study towards non conventional bionutrition. Advance Journal of Food Science and Technology, 4(1), 15-21.

Martínez-Valverde, I., Periago, M.J., Provan, G. and Chesson, A. (2002). Phenolic compounds, lycopene and antioxidant activity in commercial varieties of tomato (Lycopersicum esculentum). Journal of the Science of Food and Agriculture, 82(3), 323-330. https://doi.org/10.1002/jsfa.1035

Mohan, M. and Bhandare, S. (2012). Protective effect of solanum torvum against testicular toxicity in male wistar rats. International Journal of Pharmacy and Pharmaceutical Sciences, 4(3), 188-192.

Nenadis, N. and Tsimidou, M. (2002). Observations on the estimation of scavenging activity of phenolic compounds using rapid 1, 1-diphenyl-2picrylhydrazyl (DPPH•) tests. Journal of the American Oil Chemists' Society, 79(12), 1191. https://doi.org/10.1007/s11746-002-0626-Z

Nguelefack, T.B., Feumebo, C.B., Ateufack, G., Watcho, P., Tatsimo, S., Atsamo, A.D., Tane, P. and Kamanyi, A. (2008). Anti-ulcerogenic properties of the aqueous and methanol extracts from the leaves of Solanum torvum Swartz (Solanaceae) in rats. Journal of Ethnopharmacology, 119(1), 135-140. https://doi.org/10.1016/j.jep.2008.06.008

Oppong, L., Quain, M., Oppong, A., Doku, H., Agyemang, A. and Bonsu, K.O. (2015). Molecular Characterization of Solanum Species Using ESTSSRs and Analysis of Their Zinc and Iron Contents. Journal of Experimental Agriculture International, 6 (1), 30-44. https://doi.org/10.9734/AJEA/2015/6337

Otu, P., Sarpong, F., Gidah, J.E., Labanan, A.-M. and Anim, D. (2017). Characterization of Turkey berry (Solanum torvum)-fresh, dry and powder. African Journal of Food and Integrated Agriculture, 1, 9-14.

Panche, A., Diwan, A. and Chandra, S. (2016). Flavonoids: an overview. Journal of Nutritional Science, 5, e47. https://doi.org/10.1017/jns.2016.41

Pour, B.M., Latha, L.Y. and Sasidharan, S. (2011). Cytotoxicity and oral acute toxicity studies of Lantana camara leaf extract. Molecules, 16(5), 36633674. https://doi.org/10.3390/molecules16053663

Rasheed, A. and Qasim, M. (2013). A review of natural steroids and their applications. International Journal of Pharmaceutical Sciences and Research, 4(2), 520.

Re, R., Pellegrini, N., Proteggente, A., Pannala, A., Yang, M. and Rice-Evans, C. (1999). Antioxidant activity applying an improved ABTS radical cation decolorization assay. Free radical biology and medicine, 26(9-10), 1231-1237. https:// doi.org/10.1016/S0891-5849(98)00315-3

Sam, S., Udosen, I. and Mensah, S. (2012). Determination of proximate, minerals, vitamin and anti-nutrients composition of solanum verbascifolium linn. International Journal of 
Advancements in Research and Technology, 1(2), 110.

Sundari, S.G., Rekha, S. and Parvathi, A. (2013). Phytochemical evaluation of three species of Solanum L. International Journal of Research in Ayurveda and Pharmacy, 4(3), 27-35. https:// doi.org/10.7897/2277-4343.04323

Tettey, C., Ocloo, A., Nagajyothi, P. and Lee, K. (2014). An in vitro analysis of antiproliferative and antimicrobial activities of solvent fractions of Taraxacum officinale (Dandelion) leaf. Journal of Herbs, Spices and Medicinal Plants, 20(4), 329-340. https://doi.org/10.1080/10496475.2013.871382

Toor, R.K. and Savage, G.P. (2005). Antioxidant activity in different fractions of tomatoes. Food Research International, 38(5), 487-494. https:// doi.org/10.1016/j.foodres.2004.10.016

Truong, D.-H., Nguyen, D. H., Ta, N.T.A., Bui, A.V., Do, T.H. and Nguyen, H.C. (2019). Evaluation of the use of different solvents for phytochemical constituents, antioxidants, and in vitro antiinflammatory activities of Severinia buxifolia. Journal of Food Quality, 2019, 8178294. https:// doi.org/10.1155/2019/8178294

Waghulde, H., Kamble, S., Patankar, P., Jaiswal, B., Pattanayak, S., Bhagat, C. and Mohan, M. (2011). Antioxidant activity, phenol and flavonoid contents of seeds of Punica granatum (Punicaceae) and Solanum torvum (Solanaceae). Pharmacologyonline, 1, 193-202. 